\title{
Koinonia en diakonia as 'n missionale koninkryksdans
}

\begin{tabular}{|c|c|}
\hline \multicolumn{2}{|c|}{$\begin{array}{l}\text { Authors: } \\
\text { Johannes Ries }{ }^{1} \\
\text { H. Jurgens Hendriks }{ }^{1}\end{array}$} \\
\hline \multicolumn{2}{|c|}{$\begin{array}{l}\text { Affilations: } \\
{ }^{1} \text { Department Practical } \\
\text { Theology and Missiology, } \\
\text { Stellenbosch University, } \\
\text { South Africa }\end{array}$} \\
\hline \multicolumn{2}{|c|}{$\begin{array}{l}\text { Note: } \\
\text { This article is based on } \\
\text { the doctoral dissertation } \\
\text { of Johannes Ries ( } 2012 \text { ). } \\
\text { Prof. H.J. Hendriks was the } \\
\text { promoter. }\end{array}$} \\
\hline \multicolumn{2}{|c|}{$\begin{array}{l}\text { This article is published in the } \\
\text { section Practical Theology of } \\
\text { the Society for Practical } \\
\text { Theology in South Africa. }\end{array}$} \\
\hline \multicolumn{2}{|c|}{$\begin{array}{l}\text { Correspondence to: } \\
\text { Johannes Ries }\end{array}$} \\
\hline \multicolumn{2}{|c|}{$\begin{array}{l}\text { Email: } \\
\text { jries7@gmail.com }\end{array}$} \\
\hline \multicolumn{2}{|c|}{$\begin{array}{l}\text { Postal address: } \\
\text { Le Chasseur 52, Stelle } \\
\text { Street, Stellenryk, } \\
\text { Stellenbosch 7600, } \\
\text { South Africa }\end{array}$} \\
\hline \multicolumn{2}{|c|}{$\begin{array}{l}\text { Dates: } \\
\text { Received: } 28 \text { Mar. } 2012 \\
\text { Accepted: } 04 \text { July } 2012 \\
\text { Published: } 28 \text { Jan. } 2013\end{array}$} \\
\hline \multicolumn{2}{|c|}{$\begin{array}{l}\text { How to cite this article: } \\
\text { Ries, J. \& Hendriks, } \\
\text { H.J., 2013, 'Koinonia en } \\
\text { diakonia as 'n missionale } \\
\text { koninkryksdans' } \\
\text { HTS Teologiese Studies/ } \\
\text { Theological Studies 69(2), } \\
\text { Art. \#1249, } 8 \text { pages. http:// } \\
\text { dx.doi.org/10.4102/hts. } \\
\text { v69i2.1249 }\end{array}$} \\
\hline \multicolumn{2}{|c|}{$\begin{array}{l}\text { Copyright: } \\
\text { C 2013. The Authors. } \\
\text { Licensee: AOSIS } \\
\text { OpenJournals. This work } \\
\text { is licensed under the } \\
\text { Creative Commons } \\
\text { Attribution License. }\end{array}$} \\
\hline Read online: & $\begin{array}{l}\text { Scan this QR } \\
\text { code with your } \\
\text { smart phone or } \\
\text { mobile device } \\
\text { to read online. }\end{array}$ \\
\hline
\end{tabular}

Koinonia and diaconia as a missional kingdom dance. How does faith-based social involvement within a cultural diverse society express itself? Is the focus pure social outreach, that is, the rendering of services, or should the focus include meaningful interaction between the so called 'outreacher' and those being supported by the outreach? This article looks at the relationship between koinonia and diaconia in the creation of an intercultural space where individuals from different contexts are welcomed and supported in a mutual way. Through an interdisciplinary approach this article reflects on the experience of koinonia and diaconia in the mission of the church by bringing it into an interdisciplinary conversation with Sociology. God's reign become visible if koinonia and diaconia can dance together!

\section{Inleiding}

Hierdie artikel wil die ervaring van koinonia en diakonia in die sending van die Christelike kerk in 'n interdissiplinêre gesprek met die Sosiologie betrek. In die eerste plek wil daar gereflekteer word oor die neiging om koinonia en diakonia as twee onderskeibare funksies in die gemeentepraktyk te benader sonder om hulle integrale verweefdheid na behore te erken. Ten tweede wil hierdie artikel aan die hand van die Sosiologie en spesifiek die ontwikkelingskunde reflekteer oor die verhouding tussen die twee konsepte.

Die basiese vooronderstelling waarmee daar in hierdie artikel gewerk word, is dat die Christelike kerk se missionêre identiteit ' $n$ holistiese benadering van koinonia en diakonia veronderstel. Daardeur tree koinonia en diakonia na vore as twee wesenlike boustene van die kerk se openbare getuienis en dien dit as 'n besondere vergestalting van die koninkryk van God. Die spel tussen die twee modi kan as 'n dans beskryf word - dit veronderstel 'n fyn aanvoeling en ' $n$ sin vir die estetiese.

Die fokus op koinonia en diakonia wil geensins die belang van die ander kerklike funksies soos kerugma, marturia, leitourgia en ander ontken nie. Al hierdie funksies staan in 'n besondere relasie tot mekaar en behoort wesenlik tot die gemeentebediening. ${ }^{1}$ In die gemeentepraktyk gebeur dit egter dat koinonia en diakonia hanteer word as spesifieke funksies of bedienings waarby lidmate betrokke kan of selfs moet raak. Dit lei maklik tot 'n sterk institusionele fokus waar die individuele lidmaat se behoefte sentraal staan -'n behoefte wat dan kerklik-organisatories hanteer moet word.

Die gevaar bestaan byvoorbeeld dat die kleingroepbeweging primêr vir die bevordering van koinoinia ingerig word. Dit loop maklik uit op 'n na binne gekeerdheid waar individue se behoeftes moet aandag kry binne hulle 'geprivatiseerde waardes of individualistiese spiritualiteite' (Wuthnow 1994:200).

Guder (1998:4) wys daarop dat so 'n individualistiese gees te make het met 'n veel dieper krisis in die Christelike kerk, naamlik'n verkeerde verstaan van die kerk se identiteit - 'who we are and what we are for'. Hierdie identiteitskrisis noodsaak die Christelike kerk om haar bestaansdoel te gaan herontdek vanuit die missio Dei ['sending van God'] en 'n koninkryksgebaseerde roeping (in plaas van 'n kerkgebaseerde roeping). Vanuit 'n missionêre oogpunt gesien, lê die Christelike kerk se bestaansdoel ten diepste in die verheerliking van die Skepper God, die soeke na sy koninkryk en die verantwoordelike bekendmaking van hierdie Koning en sy wil in en vir die wêreld: 'Die kerk is geen bestaansdoel op sigself nie. Die kerk is daar vir die Koninkryk' (Newbigin 1981:4).

Jesus Christus se koms het alles met hierdie koninkryk te make. Hy het gekom sodat die mens, vanuit 'n bestaan van sondigheid en menslike nood, vrygemaak en tot ' $n$ herstelde verhouding met Hom gebring kan word. In Christus het God homself openbaar en die finale en deurslaggewende brug tussen Hom en die mensdom gebou. Deur die werking van die Heilige

1.Coenie Burger verwys in sy boek Gemeentes in die kragveld van die Gees (1999:203-260) na die vier kernbedienings van die gemeente as die koinonia, diakonia, kerugma en die leitourgia. 
Gees is Hy steeds in sy kerk teenwoordig en gebruik Hy gelowiges as instrumente om die hele kosmos met Hom te versoen. Hierdie versoeningstaak getuig van die Christelike geloof se eskatologiese verwagting. Dit is 'n einddoel wat die verwagting dra van die hoop van 'n herstelde toekoms, 'n nuwe hemel en 'n nuwe aarde - 'n einddoel wat gelowiges met mekaar deel ondanks ras, kultuur of ekonomiese status (Crenshaw 2005:146-147).

As instrumente van God se voortgaande missionêre betrokkenheid, behoort die kerk se missionêre roeping na vore te tree met 'n ernstige besorgdheid oor die menslike toestand. Knoetze (2009) skryf:

The thing that seems to stand out above all else in the sending forth of the Church then, is ... service, diaconia, the second great characteristic of the ministry of Jesus and of the Church. (bl. 60)

Hierdie betrokkenheid van Jesus by die wêreld is meer as 'n uitreik na blote fisiese nood. Waar op hierdie manier oor Jesus se sending nagedink word, word maklik vergeet dat Hy ook groot erns met die mens gemaak het in terme van sy of haar gebroke geestelike toestand en verhoudings. Jesus het gekom om die mensdom in die regte verhouding met mekaar en met God te herstel (Joh 3:16-17).

\section{Die probleem van 'n losmaak van koinonia en diakonia}

In 'n post apartheid Suid-Afrika, word die Christelike kerk deur reuse sosiale uitdagings gekonfronteer. Die South African Christian Leadership Assembly (SACLA) lig die volgende agt uitdagings uit:

MIV en VIGS
geweld
rasisme
morele verval
armoede en werkloosheid
seksisme
die familie in krisis
misdaad en korrupsie (Joubert 2006). ${ }^{2}$

In die gemeentepraktyk gebeur dit egter dat die betrokkenheid by 'n diverse kulturele samelewing en sy uitdagings maklik beleef kan word as hulpverlening en/of die bevordering van projekte (as 'n vorm van diakonia). Dit lei daartoe dat verhoudingsbou (as 'n vorm van koinonia) sterk onderontwikkel is en in sommige gevalle selfs ontbreek.

Aan die hand van kerkspieëlnavorsing in 1989, 1993, 1996, 2000 en 2005, wys Kobus Schoeman (2010:135) daarop dat '[b]ringing members of the out-group nearer is more difficult, and supporting a ministry for them is much more acceptable than accepting them as members of one's congregation.'

Die Eenheid vir Godsdiens en Ontwikkelingsnavorsing (EGON) se navorsing aangaande gemeentes se

2.Oorspronklik is net sewe sosiale uitdagings uitgelig, naamlik MIV en VIGS, geweld rassisme, morele verval, armoede en werkloosheid, seksisme, die familie in krisis, misdaad en korrupsie. In 2006 is die morele verval van die samelewing as 'n bykomende uitdaging by die SACLA gebedsversoek van die eerste kwartaal van 'n bykomende uitdaging by die
2006 ingesluit (Joubert 2006). betrokkenheid by plaaslike gemeenskappe in die Wes-Kaap, toon soortgelyk aan '... there has been little evidence that those networks and partnerships of collective action have proceeded beyond conventional activities of charity and immediate relief' (aangehaal in Swart 2006b:369).

Die gebrek aan 'n gesonde saambestaan tussen 'n betrokkenheid by sosiale uitdagings (diakonia) en die bevordering van effektiewe verhoudingsbou (koinonia) oor kulturele grense heen, hou verrykende missionêre en sosiologiese uitdagings vir die Christelike kerk in.

\section{Missionêre uitdaging}

Sonder diepgaande verhoudings wat deur die Goeie Nuus van die evangelie saamgebind word, sal die diakonia beswaarlik sy missionêre funksie (die uitbreiding van God se koninkryk) kan vervul. God het in die heilsgeskiedenis nie net na mensenood uitgereik nie, maar Hy het ook begeer om in 'n lewende verhouding met sy skepping te staan.

Volgens Knoetze (2009:50) is die grootste gevaar van 'n gemeentelike betrokkenheid by noodverligting dat die diakonia baie maklik van die bevordering van onderlinge verhoudings losgemaak kan word. Dan is dit bloot net 'n verpligting waaraan gelowiges voldoen en dit lei tot liefde sonder ware verhoudings.

Hierdie benadering van diakonia, sonder enige wesenlike koinoniale impak, is deur De Klerk (1990:29) beskryf in terme van die wyse waarop die kerk se diens van barmhartigheid deur die jare na vore getree het. Hy wys daarop dat die diakonale betrokkenheid bykans eksklusief met die diakenamp (kyk Bybeltekste soos 1 Tim 3:8-13 en Hand 6:1-6) verbind is, asook ' $n$ siening dat dienswerk ' $n$ sekere groepie mense se verantwoordelikheid is, terwyl die oorgrote meerderheid gemeentelede onbetrokke staan.

Deur op die diakonale roeping te fokus as 'n onderskeibare funksie van die gemeente (naas ander funksies), is dit in 'n groot mate van die gemeentelike koinonia losgemaak. Dit is egter 'n groot fout. Hendriks (1992:93-103) wys daarop dat die koinonia as 'n gestalte van kerkwees juis op 'n veelvoud van diensmodi behoort uit te loop. Daarsonder sal die koinonia niks meer wees as die instandhouding van 'n klub nie.

Navorsing in die sending wys daarop dat dieselfde gebrek aan koinonia ook in die sendingaktiwiteite van die twintigste eeu ervaar is. Daar het by tye 'n gesindheid geheers waarvolgens "[t]hose from the "superior civilisations" gave, in a one-way traffic, the Gospel to those who needed it to uplift them' (Hendriks 2004:73).

Vanuit 'n missionêre oogpunt ontstaan daar dus 'n groot uitdaging wanneer die fokus van uitreik slegs op noodverligting en/of projekte val, terwyl daar nooit wesenlike erns met verhoudingsbou gemaak word nie. God het nie net die menslike nood, die sonde, kom versoen nie, 
maar Hy het volwaardig mens geword om in 'n verhouding met sy skepping te staan.

\section{Sosiologiese uitdaging}

Die ongesonde skeiding tussen koinonia en diakonia getuig nie net van 'n missionêre uitdaging nie, maar ook van ' $n$ sosiologiese uitdaging. Die neiging om 'iets vir iemand anders te doen' in plaas daarvan om dit 'saam te doen', is een van die grootste uitdagings in ontwikkelingsgesprekke.

In The churches and the development debate: Perspectives on a fourth generation approach (Swart 2006a), het Ignatius Swart 'n studie van die ontwikkelingskundige David Korten se viergenerasies-benadering ${ }^{3}$ gemaak. Hy het groot klem op die behoefte aan ' $n$ meer mensgerigte (holistiese) benadering tot ontwikkeling geplaas.

\section{Korten (1990) beskryf hierdie behoefte soos volg:}

There is a need to energize decentralized action toward a peoplecentred development vision and on a much broader scale than is possible with the more focused interventions of either second or third generation strategies. (bl. 124)

Om hierdie behoefte aan ' $n$ meer mensgerigte benadering tot ontwikkeling te verstaan, is dit nodig om meer van armoede te weet. Baie van die inisiatiewe vir die hantering van armoede wat misluk, kan waarskynlik na 'n foutiewe verstaan van die probleem teruggevoer word, en/of 'n onvermoë om wesenlik erns te maak met die sisteme wat tot sodanige armoede lei.

Armoede kan as 'n sosiale fenomeen in twee oorhoofse kategorieë verdeel word, naamlik 'absolute poverty' en 'relative poverty'. Volgens Swanepoel en De Beer (2006:3) het 'absolute poverty' betrekking op ' $\mathrm{n}$ afwesigheid van die mees basiese lewensmiddele (soos kos en behuising), en 'relative poverty' betrekking op 'n gebrekkige toegang tot hulpbronne en geleenthede.

Omdat armoede verskillende vorms kan aanneem, kan dit nie as 'n onderskeibare of onafhanklike fenomeen hanteer word nie. Net so kan 'n uitsluitlike oorsaak vir armoede ook nie uitgelig word nie. Om hierdie rede verkies Chambers (1983:111) om eerder van 'n 'deprivation trap' te praat wat tot armoede, fisieke swakheid, weerloosheid, magteloosheid en isolering of vervreemding lei.

Die groot uitdaging by armoede is dus nie alleen 'n fisieke gebrek nie, maar ook die verskeie ander faktore wat tot armoede lei soos die gebrek aan hulpbronne, gebrekkige samelewingstrukture en 'n gebrek aan menslike ontwikkeling. Knoetze (2009:52) beskryf dit as 'the result of the dysfunctional interaction between complex systems'.

3.Generasie een het betrekking op nood en welsyn, generasie twee op gemeenskapsontwikkeling, generasie drie op ' $n$ volhoubare sistemiese benadering, en generasie vier het op ' $n$ meer holistiese benadering van menslike bemagtiging betrekking, ' $n$ 'people's movement' (soos ontleen van Swart 2006a:133). Hierdie betrekking, ' $n$ 'people's movement' (soos ontleen van Swart 2006a:133). Hierdie
bondige beskrywing dek egter net die mees onderskeibare kenmerke. Vir' $n$ meer volledig beskrywing is Swart (2006a:97-188) se afdeling 4.2, 'Three generations of NGO development' en hoofstuk vyf, 'The dawn of a fourth generation approach', van groot waarde.
Sosiologies lyk dit dus asof gemeentes verkeerd optree deur op barmhartigheidswerk en noodverligting te fokus, terwyl die breër sosiologiese uitdagings soos fisieke swakheid, weerloosheid, magteloosheid en isolering of vervreemding in 'n groot mate oorgesien of misgekyk word. Persoonlike interaksie is nodig wanneer met hierdie sake gehandel word.

\section{Koinonia en diakonia in die Christelike teologie}

Een van die grootste gevare vir die kerk is dat sy maklik van haar bestaansfunksie kan afwyk en in die organisatoriese handhawing van die kerk as ' $n$ instelling kan opgaan. Waar dit gebeur, sal buitestanders waarskynlik minder welkom wees en sal koinonia net om die kerk self gaan. Hierdeur sal die kerk se plek en diensknegrol (die diakonie) in die breër samelewing sterk afgewater word.

Knoetze (2009:54) wys daarop dat Christelike kerke in terme van hulle missionêre betrokkenheid geneig is om by die sosio-kerklik-politieke en teologiese arena betrokke te raak wanneer dit om spesifieke uitdagings in ' $n$ breër kulturele konteks gaan, of aan die ander kant, om meer in die geestelike behoeftes van mense belang te stel as in die sosiale welvaart van 'n gemeenskap.

Hierteenoor skryf Lindbeck (2003:155) dat die Christelike geloofsgemeenskap te alle tye beskou moet word as 'witnesses that God has chosen' en dat die kerk in terme van haar openbare mandaat die belangrike taak het om die evangelie te verkondig sowel as om die wêreld met God se liefde te bedien.

Die konsepte koinonia en diakonia tree hier sterk na vore in die ontsluiting van 'n prakties-teologiese ekklesiologie vir 'n kerk wat uit haar institusionele paradigma wil tree.

\section{Koinonia en diakonia in 'n prakties-teologiese ekklesiologie}

Heitink (1999:279-280) wys daarop dat egte koinonia spesifiek die antropologiese en diakonologiese aspekte van kerkwees aan mekaar wil verbind. In die praktyk gebeur dit egter maklik dat die gemeentelike koinonia benader kan word as 'n gemeentelike funksie (naas ander funksies) om gemeentelede bymekaar te bring of gelukkig te hou (Cairns 1981:85).

Nie alleen loop so 'n fokus uit op 'n ongesonde kompetisie tussen gemeentes vir die verskaffing van die beste 'produk' nie, maar dit het ook aanleiding gegee tot 'n grootskaalse onderwaardering van die dienskarakter (diakonia).

Manala en Dreyer ${ }^{4}$ (2001:1096-1097) beskou dit as 'n groot gevaar, want daardeur kan die persepsie maklik ontstaan dat diens (diakonia) gelyk is aan 'n 'noodfonds wanneer uitdagings na vore tree' en nie werklik deel is van die onderlinge koinonia nie. Hulle lig 'n aantal 4.Manala en Dreyer skryf vanuit die perspektief van die Hervormde Kerk in Suid-Afrika. 
redes uit waarom die dienskarakter (diakonia) nooit wesenlik gerealiseer word nie:

- Die onbetrokkenheid van lidmate rakende liefdadigheid en ander dienste.

- 'n Duidelike en selfs ontstellende gebrek aan koinonia en 'n sensitiwiteit vir menslike swaarkry.

- Die implementering van diakonale strukture sonder voldoende voorsiening in die kerkwet.

- Die afwatering van die diaken se taak tot ' $n$ insamelaar van tiendes en ' $n$ bedienaar by die nagmaal. Hierdie afwatering wys ironies genoeg op die wanvoorstelling van die Sondagse offergawes (gawes van barmhartigheid) en die nagmaal, wat ten diepste vir die armes en die onderhoud van die kerk bedoel is.

- 'n Afwesigheid van diensgroepe en strukture wat netwerkkoördinering bevorder; 'n afwesigheid van gespesialiseerdes in die relevante velde van betrokkenheid, sowel in die gemeente as op ander vlakke.

- Ongeletterdheid; 'n gebrek aan kennis en organiseringsvermoë.

- Uitermatige armoede onder kerklidmate.

- Die kerk se afhanklikheid van kulturele strukture om in die behoeftes van die armes, weduwees en die senior burgers te voorsien - strukture wat besig is om uitmekaar te val en in baie areas reeds in duie gestort het.

Hierdie redes vir 'n gebrekkige diakonia illustreer hoedat kerklidmate se talente en vermoëns baie maal oorgesien word ten koste van 'n paar leidinggewende figure (soos ampsdraers en die rol van die predikant). Dit veroorsaak dat die wesenlike uitlewing van die diakonia deur ALLE LIDMATE nooit tot sy reg kom in die gemeentebediening nie.

Waar die diakonia egter in die sin van koinonia verstaan word, daag dit hierdie statiese, selfgesentreerde strukture uit en doen dit 'n oproep tot 'n geloofsgemeenskap waarin die lede lewende instrumente van onderlinge sorg, uitdeling en heling vorm. ${ }^{5}$

Coleman (1964:27) wys daarop dat die noue relasie tussen koinonia en diakonia verteenwoordigend is van 'n lewenslange verhouding. Dit gaan nie om projekte of programme nie, maar oor ' $n$ ware besorgdheid oor diegene in die onmiddellike omgewing.

Hierdie siening sluit ook sterk aan by Hoekendijk (1965:144) wat daarop wys dat die kerk in haar geïnstitusionaliseerde natuur heeltemal ontoereikend is om meelewend binne die leefwêreld van die mensdom op te tree. Hy skryf dit toe aan 'n ernstige gebrek aan solidariteit en beskou dit as 'n radikale verskraling van wat dit beteken om die kerk van Christus te wees.

Omdat die geïnstitusionaliseerde natuur van die kerk maklik tot 'n onpersoonlike en selfs apatiese houding teenoor

5.Die belangrike funksie van ' $n$ geloofsgemeenskap is omvattend deur Hoekendijk (1965) bespreek. Hoekendijk (1965:21-31) gaan selfs so ver om te sê dat die Christelike kerk na vore behoort te tree as'n paroikia ['n nomadiese groep]. Volgens hom is dit ' $n$ 'aanpasbare' geloofsgemeenskap se taak om oral tekens van God se hom is dit ' $n$ 'aanpasbare' geloofsgemeenskap se taak om oral tekens van God se
koninkryk te gaan vestig en hierdeur tree die kerk ten diepste na vore as ' $n$ 'kerk vir andere'. wêreldsake lei, is transformasie nodig. Transformasie moet geskied vanaf 'n vorm van individualisme na 'n vorm van kollektivisme, vanaf selfbelang na korporatiewe belang, vanaf onafhanklikheid na saambestaan.

Volgens Hall (1996:64) behoort die Christelike kerk as 'n belydende kerk na vore te tree; ' $n$ kerk wat begenadig is deur die gekruisigde Een en wat as sy verteenwoordiger, die ganse wêreld met Hom wil versoen. Die kerk kan nie daar vir haarself wees nie, maar behoort daar te wees vir 'n wêreld wat smag na die koninkryk wat kom.

Dit is dus duidelik dat daar 'n noue verband bestaan tussen die betekenis om as geloofsgemeenskap byeengeroep te word en om by sosiale uitdagings betrokke te raak. Die vraag is egter: Hoe lyk so 'n geloofsgemeenskap in die praktyk? Waar vind so 'n geloofsgemeenskap sy vertrekpunt?

\section{Koinonia en diakonia in God se uitreik na die wêreld}

Wanneer die missio Dei asook die koninkryk van God as vertrekpunt vir 'n missionale gemeente geneem word, beïnloed dit nie alleen die wyse waarop die gemeente byeenkom (koinonia) nie, maar ook die wyse waarop sy haar gemeentelike betrokkenheid (diakonia) organiseer.

Die missio Dei beklemtoon dat die kerk 'n instrument is van God se sending na die wêreld. Net soos wat God sy Seun gestuur het, stuur Hy ook sy kerk na die wêreld (Bosch 1991:390). Vanuit'n missionêre oogpunt wys Bosch (1980:82) daarop dat '... the ingathering dimension supports the serving dimension, while the serving dimension in turn supports the ingathering'.

'n Uitnodigende en dienende dimensie vereis vervolgens ' $n$ meer holistiese verstaan van die kerk se missionêre roeping. By sodanige holistiese verstaan tree die gemeentelike funksies van gemeenskap (koinonia) en diens (diakonia) sterk na vore. Nie net weerspieël hierdie funksies iets van God se rol in en vir die wêreld nie, maar dit getuig ook van die mens se funksie in en vir die wêreld.

In hierdie interaksie word mense nie net deur ' $n$ gedeelde eenheid met God en Christus byeengebring nie, maar word daar ook aan hulle onmiddellike behoeftes (fisiek sowel as geestelik) aandag gegee. Sodoende word die geloofsgemeenskap 'n uitnodigende gemeenskap waar andere uitgenooi word tot geloof in Jesus Christus.

\section{In Kolossense 1:19-20 lees ons:}

God het besluit om met sy volle wese in Hom te woon en om deur Hom alles met Homself te versoen. Deur die bloed van sy Seun aan die kruis het Hy die vrede herstel, deur Hom het Hy alles op die aarde en in die hemel met Homself versoen.

Hierdie inkarnasie is uiters relevant vir die kerk se missionêre betrokkenheid by God se skepping, omdat ons juis vanuit Jesus se voorbeeld leer hoe om sy boodskap van redding in ons verhoudings en optrede te vertolk (Vermeulen 1996:91). 
Die inkarnasie veronderstel nie net dat God in Jesus Christus mens geword nie het, maar dat Hy ook deel van die ekonomiese realiteit, die politieke geskiedenis, die godsdienstige gevegte en sosiale grense van sy tyd geword het. Wainwright (1997:10) noem dit 'n menswording in die 'thick texture of his human life'.

Vanuit koinonia met die eg menslike lewe, het Jesus sy diakonia in profetiese, priesterlike en koninklike funksies uitgeleef (Wainwright 1997:121-171). Hierdie funksies kan met kennis (profeties), mag (koninklik) en versoening (priesterlik) verbind word.

Anders as kennis en mag wat gebruik kan word om vervreemding tussen 'n onderdrukker en die randfigure van die samelewing te bevorder, wou Christus eerder gestalte gee aan 'n vorm van kennis en mag wat deur liefde gekenmerk word.

So 'n liefde word beliggaam deur 'n verhouding waarin koinonia en diakonia nou aan mekaar verwant is. In sodanige verhouding gaan dit nie daarom om iets vir of aan iemand te doen (diakonia) nie, maar om ware solidariteit (koinonia en diakonia) met die mens te hê. Pederson (2007:384) beskryf dit as 'deep in the flesh with one another and with all creation'.

Juis hierom is daar 'n noue verband tussen Christus se vleeswording en die belangrikheid van menswaardigheid te bespeur. Pederson (2007:385-386) glo dat Christus se vleeswording van 'n besondere aanvaarding van God se skepping getuig, 'n aanvaarding of verhouding waartoe die kerk missionêr geroepe is.

Matteus 25:31-46 getuig byvoorbeeld van die bevordering van menswaardigheid en dit gaan om veel meer as die beoefening van diakonia (die gee van kos vir hongeres, die besoek van siekes en gevangenes en die verskaffing van klere vir diegene wat dit benodig). Diegene wat die naaste bedien, word op hulle beurt met Jesus 'the Human Being', se teenwoordigheid (koinonia) bedien, selfs al het die dienaar nie na Hom gesoek nie (Hoffmeyer 2009:155).

Hierdie ontmoeting word deur Hoffmeyer (2009) beskryf as 'n sentripetale en sentrifugale mag:

... because Jesus is a center whose being is for others, to be drawn into that center is simultaneously to be drawn out to the other for whom Jesus existed. (bl. 158)

Hoffmeyer (2009:161) waarsku teen die gevaar van 'n 'diaconal abstraction', waardeur omgee as 'n godsdienstige plig beskou word om Jesus of God se guns te wen. Hy wys daarop dat omgee veel eerder deel is van wie God in Christus is, want die 'true experience of transcendence is Jesus' being for others'. In hierdie bestaan vir andere speel die Heilige Gees ' $n$ baie belangrike rol. Dit is deur die Heilige Gees se werking wat Christus ontmoet word in die persoon wat honger of dors of mishandel is (Hoffmeyer 2009:162).

Een van die grootste gevare vir die kerk is dus ' $n$ persepsie dat die diakonia iets is wat sy moet doen, 'n opdrag wat uitgevoer moet word. By so 'n benadering val die fokus vierkantig op mense met hulpbronne wat iets moet gaan doen, soos om die hongeres te voed. Aan die een kant staan die gewers - diegene wat mense voed, diegene met hulpbronne, die agente, die verskaffers. Aan die ander kant staan die ontvangers - diegene wat gevoed word, diegene wat hulpbronne benodig, die slagoffers, diegene wat bedien moet word. Waar daar egter Christologies besef word dat Christus liggaamlik teenwoordig is in die persoon wat honger of siek is, of wat vervolg word, word ware verhoudings moontlik en vind ' $n$ besondere interaksie of ontmoeting plaas: een persoon gee geld, kos, skuiling of geselskap, terwyl 'n ander 'n storie, menslike teenwoordigheid, ' $n$ glimlag of ' $n$ traan gee. Wat ook al die omvang, sulke verhoudings dra by tot menswaardigheid sonder jammerhartigheid.

Vermeuelen (1996) skryf:

In effect, the incarnational approach becomes an ethic of evangelism, based upon the humanity of Christ, whose life and actions are much the norm of obedient Christian living as are his words. (bl. 89)

So 'n inkarnasionele benadering hou 'n belangrike interpretatiewe funksie vir die kerk se sending in:

- In die eerste plek vra dit dat die partikulariteit en verskeidenheid van 'n kulturele konteks met groot erns benader sal moet word.

- In die tweede plek vra ' $n$ inkarnasionele benadering dat evangelisasie volgens Christus se voorbeeld gedoen moet word.

\section{Koinonia en diakonia vanuit 'n sosiologiese perspektief ${ }^{6}$}

Aan die hand van die industriële en koloniale periode van die wêreldgeskiedenis, wys Swart (2006a:12) daarop dat die Christelike kerk se betrokkenheid by sosiale uitdagings primêr in die vorm van liefdadigheid na vore getree het. ${ }^{7}$ Dit het daartoe gelei dat egte solidariteit (koinonia) met die armes of gemarginaliseerdes van die samelewing gering of in ' $n$ groot mate afwesig was. So 'n ervaring van sosiale betrokkenheid noodsaak die belangrikheid van 'n godsdienstige ondersteuningsnetwerk waar die klem nie net op ' $n$ onderlinge eenheid tussen die verskillende lede val nie, maar 'n betrokkenheid wat verder as oppervlakkige liefdadigheid strek.

In die Sosiologie word besef dat dit noodsaaklik is om weg te beweeg vanaf 'n kollektivistiese (homogene) en 'n outonome (individualistiese) benadering van gemeenskap na 'n meer personalistiese benadering. Dit wil in werklikheid 'n versoening van eersgenoemde twee modelle wees (Aku 2000:96).

6 . Hierdie afdeling het ten doel om die kerk as'n sosiale beweging te rekonstrueer. Vir ' $n$ meer omvattende bespreking van die sosiologiese konsepte van solidariteit soos die onderskeid tussen Gemeinschaft en Gesellschaft, die konsepte homogeniteit en ligging, die selfakualisering van die peroon deur solidariteit en menslike samehorigheid, vergelyk Ries (2012:63-72).

7.Swart (2006a:12) skryf: 'This assumption (which can be found explicitly in a number of the essays and implicitly in the others) is that in those instances where the churches did in fact respond to the plight of the poor and the social problems that erupted in the wake of the social changes brought about by the industrial revolution erupted in the wake of the social changes brought about by the industrial revolution
and subsequent colonial expansion, the response in general merely involved a mode of social engagement that could be defined by the notion of charity.' 
Vir sosioloë soos John Macmurray (1961:127-128) het solidariteit juis betrekking op 'n positiewe en persoonlike vereniging van persone, waardeur ' $n$ holistiese benadering van persoonskap tot stand kom. Sodoende word die persoon nie net in terme van sy of haar individualiteit benader nie, maar ook in terme van die samelewing en strukture waarin hy of sy leef. Gibson Winter (1981:27) brei op hierdie personalistiese perspektief uit (waar die individualiteit van die mens in versoening met 'n gemeenskaplike doelwit gebring word) deur na ' $n$ 'artistic process' te verwys om 'human dwelling' te bewerkstellig. Hy beskryf die 'artistic process' as 'n positiewe versoening van die organiese, intieme vorms van gemeenskap en 'n besorgdheid oor die breër samelewing of ekologie. Gevolglik tree die menslike persoon by 'n personalistiese benadering na vore as 'n aktiewe agent wie se funksies definitiewe implikasies in 'n breër sosiale raamwerk (die samelewing en selfs die groter kosmos) inhou.

Aku (2000:107) voer op soortgelyke wyse aan dat 'n personalistiese benadering van gemeenskap nie net om 'n voorsiening in die primêre behoeftes van die mens gaan nie, maar ook om die morele vorming van die mens vir die openbare welvaart van die breër samelewing. By so 'n personalistiese benadering van gemeenskap gaan dit dus om die bewerkstelliging van verbintenisse op twee vlakke:

1. Die daarstelling van interpersoonlike verbintenisse of aangesig-tot-aangesig verbintenisse (sosialisering).

2. Die daarstelling van meer uitgebreide verbintenisse wat gepaard gaan met moraliteit en waardes soos geregtigheid, eerlikheid, lojaliteit en betroubaarheid.

Vanuit 'n ontwikkelingsoogpunt is dit dus nodig dat kerke in terme van sosiale betrokkenheid wyer moet dink as primêre hulpverlening en noodverligting. ${ }^{8}$ Dit is op grond hiervan dat Korten (1990:163-169) die belangrikheid van 'reconciliation' en 'spiritual development' as deel van die sosiale proses beskou.

Om die rol van kerke as 'n sosiale beweging beter te verstaan, beskryf Swart (2006a:192, 198-199) kerke as 'people's organisations (POs)' wat kollektief deur hulle lede bestuur en besit word op grond van hulle gedeelde geloof en waardes. Sulke 'people's organisations' baan die weg tot wat Castells (2004:422-423) 'project identity' noem. Daardeur word kerke uitgenooi om nie net die armes, gemarginaliseerdes en onderdruktes te ondersteun nie, maar hulle ook te bemagtig (as deel van 'n 'project identity formation process').

'n Goeie voorbeeld van 'project identity'-vorming is die Ecclesial base communities (CEBs) $)^{9}$ van Suid-Amerika.

8. Rein Brouwer (2009) werk in Geloven in gemeenschap sterk met die sosiologiese konsepte van 'bonding' en 'bridging' om die Protestantse Kerk in Nederland se bydrae tot sosiale kapitaal te belig. Volgens Brouwer (2009:372-383) is die Protestantse Kerk in Nederland vasgevang in wat hy noem 'bonding' sosiale kapitaal en nie in staat om in breër samelewingsnetwerke vir die bevordering van vertroue en wederkerigheid te belê nie. Hy lig 'n groot onvermoë uit in die 'bridging' van die en wederkerigheid te bele nie. Hy lig ' $\mathrm{n}$ groot onvermoe uit in die 'bridging' van die sosiale-, kulturele- en ekonomiese leefwêreld van oud en jonk, ryk en arm, plaaslike mense. Vir meer inligting oor 'bonding' en 'bridging', vergelyk veral Putnam (2000).

9.Die oorspronklike naam is las Comunidades Eclesiales de Base (CEB). Hierdie CEB9.Die oorspronklike naam is las Comunidades Eclesiales de Base (CEB). Hierdie CEB-
model tree na vore as'n uitgebreide netwerkgemeenskap van die kerk wat rondom model tree na vore as'n uitgebreide netwerkgemeenskap van die kerk wat rondom movement' sentreer (Swart 2006a:201).
Hierdie gemeenskappe gee op 'n unieke wyse gestalte aan wat David Korten (1990:100) 'people's organisations' noem. In sodanige gemeenskappe ontvang die tradisioneel gemarginaliseerdes en onderdruktes die geleentheid om saam te dink, te praat en op te tree (Swart 2006a:201).

Ulrich Duchrow (1995:246-247) verwys op soortgelyke wyse na La Poudrière, 'n gemeenskap van ongeveer vyf interafhanklike gemeenskappe van meer as 100 mense wat in die omgewing van Brussels woon. Hulle het as 'n groepie huislose en werklose mense byeengekom om allerhande afvalprodukte te herwin. Mettertyd het hulle tot 'n uiters gesofistikeerde en selfonderhoudende gemeenskap ontwikkel.

Geïnspireer deur kerke se eie boodskap van 'n bevrydingsteologie en die model van Ecclesial base communities word dit al hoe meer noodsaaklik dat daar groter erns met die mens gemaak moet word in terme van sy of haar geestelike, politieke, sosiale, kulturele en ekonomiese uitdagings. So 'n benadering beteken egter nie dat die kerk of die Christelike geloof al die omgewings-, ekonomiese, politieke en sosiale probleme moet oplos nie. Dit beteken veel eerder dat die kerk en Christelike geloof 'n onmiskenbare bydrae kan maak tot die hantering daarvan.

Swart (2006a:208-209) omskryf hierdie bydrae as 'n 'spiritual renewal' en die vestiging van 'n 'soft culture' met die volgende kenmerke:

- Die ontwikkeling van 'n groter besorgdheid ('n hulpvaardige gees) teenoor die sogenaamde ander, asook die bewerkstelling van respek ('n gees van aanvaarding) vir elke ander persoon of groep - volgens ras, etnisiteit of godsdienstigheid.

- Die ontwikkeling van ware medelye met diegene wat ly, met ' $n$ spesiale besorgdheid oor kinders, bejaardes, armes, gestremdes, vlugtelinge en vervreemdes.

- Die bevordering van gemeenskaplike respek en erkenning vir die voorkoming van gesags- en/of magsmisbruik, asook die moontlikheid van botsings weens uiteenlopende belange.

- 'n Herwaardering van matigheid en nederigheid as teenvoeter vir 'n allesverterende stryd om geld, prestasie en verbruik.

- Die daarstelling van 'n gees van betroubaarheid in alle verhoudings, in plaas van oneerlikheid, skynheiligheid en opportunisme.

- Die ontwikkeling van gemeenskaplike respek, vennootskap en bedagsaamheid by persoonlike en familiale verhoudings, in plaas van patriargale oorheersing en afbreking.

- Die skep van 'n gees van gedeelde besorgdheid, aanvaarding, gereedheid vir versoening en liefde, in plaas van een of ander vorm van besitlikheid of misbruik.

\section{Samevatting}

Vanuit die benadering van koinonia en diakonia in hierdie artikel is aangevoer dat ' $n$ uitsluitlike bemoeienis met die eie 
kerkgemeenskap en die bevordering van 'n gemeentelike koinonia, sonder 'n besorgdheid oor die breër sosiale konteks vanuit 'n teologiese oogpunt,onaanvaarbaar is.

Vanuit die kerk se missionêre roeping kan sy vir geen oomblik 'n selfgenoegsame kerk wees nie. Sy behoort funksioneel op die herstrukturering van God se koninkryk gerig te wees - 'n voortgaande proses wat deur God se betrokkenheid in die wêreld begin is.

Om die behoeftes van ons naaste te leer ken, is in werklikheid die eerste stap op die weg na betekenisvolle herstel en verandering. Dit vra egter om 'n verhouding - 'n verhouding waarin daar saam na verskeie uitdagings geluister en saam opgetree word.

Die onderbeklemtoning van so 'n gemeenskapsbewussyn is duidelik waarneembaar in die wyse waarop teologie deur die jare beoefen is. Müller (1970:189-194) ervaar byvoorbeeld die gemeenskapsdimensie in die teologie, veral in die pastoraat, as ontoereikend en pleit vir'n groter beklemtoning van die gemeenskapsdimensie van die geloof. As oplossing vir so 'n eensydige, individualistiese en psigoterapeutiese benadering, voer Müller (1970:192) aan dat die pastorale sorg koinoniaal gestruktureer moet word. Daardeur plaas hy besondere klem op die belangrikheid van integrationskerne, as 'sterk bande van warme medemenslikheid en onderlinge steun'.

Vervolgens is dit noodsaaklik dat gemeentes vandag hulle gemeentelede op so 'n wyse sal toerus dat dit vir hulle in die eerste plek nie gaan om 'n tuiskoms in koinonia nie, maar dat die soeke na 'n koinonia tussen God en sy kerk, sy wêreld, sy skepping, juis hulle sal inspireer om aan ware integrationskerne te gaan bou.

Koinonia en diakonia is belangrik vir die getuienistaak van die kerk, maar daar sal doelbewus teen 'n oorbeklemtoning van die een funksie ten koste van die ander gewaak moet word. Albei hierdie funksies speel 'n wesenlike rol in die identiteit van die kerk en waar daar nie 'n gesonde balans gehandhaaf word nie, ontstaan karakterverlies.

Waar groot klem op koinonia in die konteks van die plaaslike gemeente geplaas word, is daar 'n geneigdheid om kerklike strukture met 'n mate van agterdog te bejeën. Die meeste strukture vir die bevordering van koinonia is op die kerk self gerig en dus kom 'n selfgesentreerde kerk maklik na vore.

Wanneer die diakonale funksie van die kerk oorbeklemtoon word, verabsoluteer dit die gestuurdheid van die kerk na die wêreld en is die kerk se funksie in werklikheid niks meer as maatskaplike hulpbetoon nie. Tog beskou Berkhof (1986:415) hierdie spanning as 'n noodsaaklike gebeurtenis in die belewing van koinonia en die uitlewing van diakonia.

Aan die een kant is koinonia afhanklik van diakonia vir 'n egte gemeenskapslewe en aan die ander kant is diakonia weer van koinonia afhanklik vir 'n meer doeltreffende en effektiewe betrokkenheid. Koinonia wil nie net kohesie tussen mense bevorder nie, maar ook lewenskragtige en lewensvatbare strukture tot stand bring om mense, ten spyte van verskille en sosiale groeperings, te verenig. So ' $n$ vorm van koinonia vra nie alleen respek vir die ander nie, maar 'n daadwerklike ontmoeting met die ander.

Koinonia en diakonia daag dus die Christelike geloof en kerk uit om hulle ware sterk punte en bydraes tot ontwikkeling te gaan ontdek (néé, herontdek!) vir die bewerkstelling van 'n meer regverdige en menswaardige samelewing. Gemeentelike betrokkenheid by sosiale uitdagings behoort in die eerste plek nie om liefdadigheid of projekte te gaan nie, maar om die skep van 'new relationships of solidarity and coalition with the contemporary movements of the poor and civil society with which they have (or ought to have) much in common' (Swart 2006a:242).

Miskien lê die grootste probleem aangaande armoede nie so seer by 'n gebrek aan hulpbronne nie, maar eerder by 'n gebrek aan ware koinonia met die naaste. Gelowiges moet leer dans - leer uitreik na mekaar om 'n fyn aanvoeling vir die ander te ontwikkel en saam 'n aanvoeling te ontwikkel vir die leiding van die Heilige Gees sodat die koms van die koninkryk daardeur sigbaar gestalte kan vind.

\section{Erkenning Mededingende belange}

Die outeurs verklaar dat hulle geen finansiële of persoonlike verbintenis het met enige party wat hulle nadelig kon beïnvloed in die skryf van hierdie artikel nie.

\section{Outeursbydrae}

Die navorsing vir die artikel is gedoen deur J.R. (Universiteit van Stellenbosch) onder leiding van H.J.H. (Universiteit van Stellenbosch). Dit is gebaseer op J.R. se doktorale proefskrif en daar is saamgewerk in die verwerking daarvan in artikelvorm.

\section{Literatuurverwysings}

Aku, E., 2000, Re-defining community, Peter Lang, Frankfurt.

Berkhof, H., 1986, Christian faith: An introduction to the study of faith, Eerdmans, Grand Rapids.

Bosch, D.J., 1980, Witness to the world: The Christian mission in theological perspective, Marshall, Morgan \& Scott, London.

Bosch, D.J., 1991, Transforming mission: Paradigm shifts in theology of mission, Orbis Books, New York.

Brouwer, R., 2009, Geloven in gemeenschap: Het verhaal van een protestantse geloofsgemeenschap, Kok, Kampen.

Burger, C., 1999, Gemeentes in die kragveld van die Gees, Buvton, Stellenbosch.

Cairns, E.E., 1981, Christianity through the centuries: A history of the Christian church, Academic Books, Grand Rapids.

Castells, M., 2004, The power of identity, 2nd edn., Blackwell Publishing, Malden.

Chambers, R., 1983, Rural development: Putting the last first, Wiley, New York.

Coleman, R.E., 1964, The master plan of evangelism, Fleming \& Sons, Inc., Westwood.

Crenshaw, J.L., 2005, Defending God: Biblical responses to the problem of evil, Oxford University Press, New York.

De Klerk, J.J., 1990, 'Die diens van barmhartigheid as koinoniale bediening', in J.J. de Klerk (red.), Die diens van barmhartigheid en die Nederduitse Gereformeerde Kerk, bl. 21-35, NG Kerk-Uitgewers, Kaapstad.

Duchrow, U., 1995, Alternatives to global capitalism: Drawn from biblical history, designed for political action, International Books, Utrecht. 
Guder, D.L., 1998, Missional church: A vision for the sending of the church in North America, Eerdmans, Grand Rapids.

Hall, D.J., 1996, Confessing the Faith, Fortress Press, Minneapolis.

Heitink, G., 1999, Practical Theology: History, theory, action domains, Eerdmans, Grand Rapids.

Hendriks, H.J., 1992, Strategiese beplanning in die gemeente, Hugenote-Uitgewers, Wellington.

Hendriks, H.J., 2004, Studying congregations in Africa, Lux Verbi.BM, Wellington

Hoekendijk, J.C., 1965, De kerk binnenste buiten, Ten Have, Amsterdam.

Hoffmeyer, J.F., 2009, 'Christology and diakonia', in A. Schuele \& G. Thomas (eds.), Who is Jesus Christ for us today?, pp. 150-166, Westminster John Knox Press, Louisville.

Joubert, W., 2006, 'SACLA call to prayer for South Africa' (no. 7: First Quarter 2006), in South African Christian Leadership Assembly, viewed 17 March 2010, from http:// www.sacla.za.net/?component=ddb\&operation=page\&page $=15$

Knoetze, H., 2009, 'Missional diaconia: A perspective on ministry in our context', in J. du Plessis, E. Orsmond, \& H. van Deventer (eds.), Missionary perspectives in the New Testamanent, pp. 49-62, Bible Media, Wellington.

Korten, D.C., 1990, Getting to the 21st century: Voluntary action and the global agenda, Kumarian Press, West Hartford.

Lindbeck, G.A., 2003, The church in a post-liberal age, Eerdmans, Grand Rapids.

MacMurray, J., 1961, Persons in relation, Faber \& Faber, London.

Manala, M.J. \& Dreyer, T.F.J., 2001, 'A service model for diakonia in the Hervormde Kerk in Suidelike Afrika', HTS Teologiese Studies/Theological Studies 57(3/4) 1096-1118. http://dx.doi.org/10.4102/hts.v57i3\&4.1872
Müller, B.A., 1970, 'Die terapeutiese waarde van die gemeenskap van die Heiliges in die pastorale sorg', Nederduitse Gereformeerde Teologiese Tydskrif, (Junie) 189-194.

Newbigin, L., 1981, Sign of the kingdom, Eerdmans, Grand Rapids.

Pederson, A.M., 2007, 'Christmas and the reality of incarnation: Finitum capax infiniti', Word \& World 27(4), 381-389.

Putnam, R.D., 2000, Bowling alone: The collapse and revival of American community, Simon \& Schuster, New York.

Ries, J., 2012, 'Koinoniale en diakonale gestaltes van die missionale gemeente binne 'n konteks van multi-kulturaliteit', DTh proefskrif, Departement Praktiese Teologie en Missiologie, Universiteit van Stellenbosch.

Schoeman, K., 2010, 'The racial discourse and the Dutch Reformed Church: Looking through a descriptive lens towards a normative task', Acta Theologica 30(2), 130-151.

Swanepoel, H. \& De Beer, F., 2006, Community development: Breaking the cycle of poverty, Juta Academic, Lansdowne.

Swart, I., 2006a, The churches and the development debate: Perspectives on a fourth generation approach, Sun Press, Stellenbosch.

Swart, I., 2006b, 'Churches as a stock of social capital for promoting social development in Western Cape Communities', Journal of Religion in Africa 36(3/4), 346-378. http://dx.doi.org/10.1163/157006606778941913

Vermeulen, P., 1996, 'Mission in Christ's way: An incarnational model for mission,' MTh thesis, Department Practical Theology \& Missiology, Stellenbosch University.

Wainwright, G., 1997, For our salvation: Two approaches to the work of Christ, Eerdmans, Grand Rapids.

Winter, G., 1981, Liberating creation: Foundations of religious social ethics, Crossroads Publishing, New York.

Wuthnow, R., 1994, Sharing the journey: Support groups and America's new quest for community, The Free Press, New York. 